CSCSTI 18.41.09

UDC 784.5

DOI 10.47940/cajas.v6i3.461

\section{МӘДЕНИЕТІНЕ ӘCEPI}

\author{
Дилара Қарекенова ${ }^{1}$ \\ ${ }^{1}$ Қазақ ұлттық өнер университеті \\ (Нұр-Сұлтан, Қазақстан)
}

Аңдатпа. Мақала Ғазиза Жұбанова ораторияларының орындаушылық практикасын зерттеуге бағыталған. XX ғасырдың 60-90 жылдар аралығында жазылған ораториялары қазақ хор мәдениетінің бағалы үлгісі ретінде қалыптасып қана қоймай, жалпы қазақ хор мәдениетінің даму үрдісін жаңа сатыға көтерген. Соңғы жылдары Ғ. Жұбанованың жалпы хор шығармашылығы кең ауқымда зерттелуде. Бірақ, нақты ораториялық шығармашылығының тарихы мен практикалық маңызы мәселесі назардан тыс қалуда. Композитор ораторияларының кеңестік кезеңдегі және тәуелсіз Қазақстан сахнасындағы орындалу тарихы түрлі кезеңдегі вокалдық-симфониялық жанрдың өзектілгін арттырады. Сондықтан, бұл мақаланың негізгі мақсаты оратория жанрының орындаушылық тарихы негізінде жанрдың ұлттық хор мәдениетін қалыптастыру мен дамыту негіздеріне әсерін анықтау болып табылады.

Қазақ хор мәдениетіндегі ораторияның жанрлық сипаты оның толық тарихи кезеңінде (1960-2020) бекіту үшін ұлттық тарихи тәжірибе оратория өнері жалпы - әлемдік процестермен байланыстырылды. Бастапқы әдістемелік ұстаным - бұл құбылыстың бөлінбейтін біртұтастық ретінде танылуында. Мақалада оратория жанры, музыка өнеріндегі шығармашылық ерекшеліктері, премьералар мен басылымдардағы орыс және батыс еуропалық классиктердің ораториялық шығармаларының ғұмыры бойынша ғылыми білімдер жинақталды. Материал ретінде - Ғ. Жұбанова ораторияларының музыкалық мәтіндері, баспа және қолжазба күйінде сақталған клавирлері, аудио және бейне жазбаларда ұсынылып отыр. Ғ. Жұбанова ораторияларының сахналық практикасын зерттеу барысында тарихи-патриоттық тақырыптағы ораториялардың ішінде “мерейтойлық ораториялар" тобының ерекшеліктері анықталды. Яғни, ораториялардың орындаушылық практикасы тікелей тақырыптық ауқымға тәуелді болды. Зерттеу нәтежесін талқылау барысында, Жұбанова ораториялары "тарихи-патриоттық", "мерейтойлық" және "философиялық" топтарға жіктелді. Оның себебі, тақырыптық негізі ғана емес, сонымен қатар, жазылу тарихы мен сюжеттік даму ерекшеліктері ретіндегі құндылығында. Зерттеу нәтижелері музыкатану ғылымдарының “вокалдық музыка” бағытындағы ізденушілер 
үшін практикалық маңыздылыққа ие. Жұбанованың ораториялық музыкасына қатысты зерттеулерді негізге алу, жалпы қазақ хор музыкасы немесе қазақ композиторларының ораториялық шығармашылығы тақырыбын тереңірек зерттеуге мүмкіндік туғызады.

Тірек сөздер: Ғазиза Жұбанова ораториялары, қазақ хор мәдениеті, орындаушылық практикасы, оратория тақырыбы, ораторияның жанрлық ерекшеліктері.

Дәйексөз үшін: Қарекенова, Дилара. «Ғазиза Жұбанова ораторияларының заманауи қазақ хор мәдениетіне әсері». Central Asian Journal of Art Studies, т. 6, № 3, 2021, 108-120 б. DOI: 10.47940/cajas.v6i3.461.

\section{Kipicne}

Ғ Ж жұбанова қазақ классикалық бірі болып табылады. Композитордың әр шығармасы классикалық музыка жанрларының қазақ музыка мәдениетіндегі қалыптасуының негізін құрады. Ол тікелей авторлық хор a'capellaдан бастап, ірі көлемді вокалдық-симфониялық жанрлардан жалғасын тапты. Ғ. Жұбанова қазақ музыка мәдениетіндегі оратория жанрының бастамасында болды. С. Мұхамеджановтың «Ғасырлар үні» ораториясымен бір кезеңде жарық көрген, «Арайлап атқан таң» ораториясы, Композиторлар одағы съезінде жоғары бағаға ие болған. Жалпы, композитордың 7 ораториясы бар. Олар: «Арайлап атқан таң» (1960), «Ленин» (1962), «Арал аңызы» (1978), «Нан мен ән» (1980), «Салтанатты оратория» (1982), «Татьяна әні» (1983), «Возлюби человек человека» (1987), (Джумакова, Абдрахман 107).

Композитор шығармашылығының түрлі кезеңдерінде жарық көрген ораториялар, екі ірі тақырыпты қамтиды. Бірінші, тарихи-патриоттық ораторияларға, композитор

шығармашылығының алғашқы кезеңінде жазылған бес оратория жатады. Жалпы Ғ. Жұбанова шығармашылығында тарихи-патриоттық шығармалар ерекше орынға ие («Двадцать восемь» операсы, «Менің республикам» хоры). Екіншісі, композитор шығармашылығының сонғы кезеңінде жазылған, философиялық ораториялар. Олардың мазмұндық тереңдігі, композитордың жеке өмірінде және ел тарихында орын алған оқиғалардың ауыртпашылығы әсер еткен.

Ғ. Жұбанованың алғашқы бес ораториясы Кеңес музыкасының мадақтау нақышындағы салтанатты көңіл күйді ұстанып қана қоймай, Шапаев, Ленин сынды тұлғалық бейнелер арқылы ерлік, жанашырлық және адалдық сынды адами қасиеттерді насихаттауды мақсат етеді. Оратория көпшілікті тәрбиелейтін, қоғамдық сана қалыптастырушы және әсер ету ауқымы кең жанр болғандықтан, ғ. Жұбанова ораторияларының тақытыптық негізгі қоғамдық қызметін атқара алды деуге болады.

Зерттер барысында Ғ. Жұбанованың тарихи-патриоттық ораторияларын тарихи ерекшеліктеріне сай «тұлғалық», «мерекелік» және «сюжеттік» деп бөлуге болады. Алғашқы топ ораториялары, аталуына сай, жеке тұлғаның ел тарихындағы елеулі еңбегін насихаттауға бағытталса («Ленин»), екінші топ ораториялары, белгілі мемлекеттік іс-шараға арнайы тапсырыс бойынша жазылған үлгі болып табылады («Нан мен ән», «Салтанатты оратория»). Үшінші топ ораториялары, композитордың жеке авторлық идеясы негізінде пайда болған шығарма болып табылады ( «Арайлап атқан таң», «Арал аңызы»). Соңғы топ ораторияларының поэтикалық негізінің өзі ерекше талдауды талап етеді. Композитордың Ғ. Мүсіреповтың 
«24 сағат» және X. Ерғалиевтің

«Оралдағы отты күндер» шығармаларын

оқығаннан кейін алған әсері негізінде

пайда болған шығармашылық

идея, сюжеттік баяндау негізі

мен драматургиялық шешімі бар,

ораториялық жанрда іске асты

(Жубанова 185).

Ғ. Жұбанова шығармашылық эволюциясының соңғы кезеңінде жарық көрген, философиялық ораториялар, алдыңғы кезең ораторияларынан өте өзгешеленеді. Кеңес музыкасына сай «мадақтау» формасынан саналы бас тарту мен тақырыптық тереңдік композитордан жаңа көркемдік шешімдерді талап етті. Композициялық шешімдер ауқымы камералық үндестік бағытына бет бұрды. Композитордың шығармашылық жетілу кезеңіне тұспатұс келген, кеңес әйелдер делегация құрамындағы Францияға іс-сапары, алғашқы қазақ әйел-композитордың алдына феминистсік, қоғамдағы әйел тұлғасының маңыздылығын насихаттау мақсатын белгіледі.

\section{Материалдар мен әдістер}

Ғ. Жұбанова ораторияларының қазақ хор мәдениетіне әсерін анықтау жұмысы жан жақты зерттеу әдістемесін талап етті. Ораториялардың шығу тарихын, композитор шығармашылығын эволюциялық қырынан қарастыру әдісі, композитордың түрлі кезеңдерде пайдаланған композициялық құралдары мен стильдік ерекшеліктерін анықтауға мүмкіндік берді.

Композитордың 7 ораториясының мазмұны мен шығу тарихын зерттеу, орындаушылық практика мәселесін шешуге жол ашты. Арнайы мемлекеттік іс-шараға тапсырыс бойынша жазылған ораториялардың премьералық орындаудан кейін ұмытылып қалуы, Ленин, Шапай сынды тарихи тұлғалардың заманауи өзектілігін жоғалтуында болып табылады. Мұндай жағдай ораториялардың әдеби мәтінін өзгертіп, жаңа нұсқада орындауға деген талабын қалыптастырады. Осы тұрғыда, жалпы оратория жанрының кеңестік және тәуелсіз Қазақстан сахнасындағы өзектілік деңгейі сөз болады. Өткен ғасырдың 60-80 жылдарында ең өзекті, саяси маңызды және концерттік практикада бірінші орынды иеленген оратория жанрының заманауи жағдайы, қазақ хор мәдениетінің даму процестерімен тұстастығынан туындайтындығы анықталады.

Сонымен қатар, сан-түрлі жанрларды қатар алып жүре білген, Ғ. Жұбанова шығармашлығындағы жанраралық байланыстар да ерекше назарды талап етті. Ә. Мәмбетовпен бірлескен жұмысы нәтижесінде пайда болған, спектакльге арналған музыкалар қоры, композитордың оратория, опера сынды сюжеттік-драматургиялық жанрларға деген жаңа көзқарасын қалыптастырғаны сөзсіз. Осы тұрғыда, Ғ. Жұбанова шығармашылығының тек қазақ хор мәдениетіне емес, жалпы өнер кеңістігіне, театр, кино және әдебиетке әсері сөз болады (Сапарова 58).

\section{Нәтижелер}

Ғ. Жұбанова ораторияларының осы зерттеу жұмысында тарихи-патриоттық және философиялық ораториялар деп екі топқа жіктелуі шығарманың жазылу тарихына ғана емес, онымен қатар сахналық ғұмырына да байланысты болды. Көбіне қоғамдық маңызды ісшаралар (Қазақстан композиторлар одағының III съезды, «Тың игеру» саясаты) мен мерейтойларға (В. И. Лениннің 100-жыл, Қазақстанның Ресейге қосылуына 250-жыл) арнап жазылған шығармалары ортақ дәстүрлі дәріптеу (славление) формасына енгізген ерекшелігі негізінде біріктірілді. Ал, композитордың аса патриотты көңілкүйден саналы түрде бас тартуы айқын көрініс тапқан үлгілері композитор 
шығармашылығының соңғы жылдарында жарық көрген терең толғанысқа толы, философиялық ойлар тұрғысынан қарастырылды.

Әр топтамадағы шығармалар, пайда болған кезеңінде аса өзекті саналып, композиторлардың жоғары марапаттарды иеленуіне себепші болып қана қоймай, сол кезеңнің тақырыптық даму бағытын анықтады. Осы ораториялардың премьералық орындауынан кейін көп мөлшерде жазылатын мақалалар мен музыка сыншыларының пікірлері қазақ музыка өнерінің өкілдеріне ғана емес, сонымен қатар, театр, бейнелеу өнері және әдеби салаларға да әсерін тигізбей қоймады. Осы тұрғыда диссертация тақырыбында кездесетін «резонанс» сөзі композитор мұрасының уақыт пен кеңістік аясындағы әсерін анықтайды.

M. Томашевскийдің «Шопен: адам, шығармашылық резонанс» атты еңбегінде композитор шығармашылығының замандастарына да, кейінгі кезеңнің музыканттары мен сыншыларына да тигізген зор әсері, осы «резонанс» түсінігімен берілген.

Ал, ғ. Жұбанова өз алдына қазақ музыкасына жаңа бағыттар мен композиторлық шешімдерді еңгізудің үлгісі ретінде белгілі болды. Терең философияға толы камералық үлгілерден бастап, ірі симфониялық жанрларға дейінгі ауқымды қамтыған шығармашылығы қазақ композиторларына шабыт шамшырағы ретінде қызмет етіп қана қоймай, қазақ орындаушылық мәдениетінің жаңа кәсіби кезеңге деген талпынысын оятушы «резонанс тудырушы» күшін қалыптастыра алды» деген (Томашевский 151 ).

Ғазиза Ахметқызының жеке естеліктеріне тоқталатын болсақ (Менің Музыка Әлемім), композитордың Мәскеудегі студенттік шағынан қалыптасқан А. В. Молодов пен Гүльжазира Ахметовамен тығыз шығармашылық байланысы дәл осы оратория жанрындағы жетістіктеріне жол ашқан. Қазақ хор мәдениетінің даму тарихында үлкен резонанс тудырған « Ғасырлар үні» және «Арайлап атқан таң» ораториялары, кәсіби композиторлық мектептің жаңа жетістігі болып қалыптасып қана қоймай, қазақ хор мәдениетінің жаңа даму бағдарын белгілеп берді.

1960 жылы жазылған «Арайлап атқан таң» ораториясы алғашқы рет 1962 жылы Мәскеу қаласында өткен Жас композиторлардың бүкілодақтық шығармашылық көрмесінде орындалып, дипломдық марапаттауға ие болған еді. Кейін, 1964 жылы Ғ. Жұбанова осы ораториясы үшін Қазақстанның Ленин комсомол сыйлығының лауреаты атағын алды. А. В. Молодовтың «Хор дирижерлеу» мамандарын даярлауға арналған арнайы хор жинағына енген ораторияның қорытынды бөлімі, көп жылдар бойы Қазақ ұлттық консерваториясының студенттерінің күнделікті оқу құралына айналып қана қоймай, Мемлекеттік емтихандарда жиі орындалып тұрған.

«Арайлап атқан таң» ораториясының сахналық тарихы кеңестік кезеңге ғана тиісті. Ораторияға негіз болған Ғ. Мүсіреповтың «24 сағат» әңгімесінің сюжеті мен Сағи Жиенбаев жазған поэтикалық мәтіні тәуелсіз Қазақстан сахнасында заманауи оқылуын таппады. Жаңа заманда азаматтық соғыс пен халық қаһарманы Шапайдың батырлық бейнесі өзектілігін жоғалқанымен, ұлттық бостандық жолындағы жанкешті күрес тақырыбы ешқашан өзектілігін жоғалтпайтыны сөзсіз. Осы тұрғыда, «Арайлап атқан таң» ораториясының аса көркемдік құндылығын иеленген бөлімдеріне жаңа мәтін жазу үрдісі қолға алынса болады. Заманауи мәтін жазу арқылы орындаушылық практикаға енгізілген өткен ғасыр шығармалары, қалың жұртшылықтың ішінде жоғары бағаға иеленуі қазақ хор мәдениетінде жие кездесетін құбылыс.

Қазақстанда дирижерлік білім беру бағдарламалары Ресейлік немесе жалпы 
әлемдік оқу стандарттарына негізделген. Орта және жоғары арнайы білім беру орындарында студенттер орыс және әлем классиктерінің шығармалары негізінде білім алуға мәжбүр. Бірақ, Ғ. Жұбанова, С. Мұхамеджанов сынды қазақ композиторларының қазақ классикасын құрайтын туындыларының терең тартпада жатып, болашақ буын музыканттарының есту кеңістігінде болмауы үлкен қателік. Ғ. Жұбанова ораториялары кезінде «ізбасарлар» шығармашылығына бағыт бағдар беріп, «жалғастырушылар» өнеріне шабыт беріп, «еліктеушілер» тобына жаңа мүмкіндіктер тудырған. Ораториялық жанр қазақ хор мәдениетін ең жоғарғы сатысы ретінде қалыптасып қана қоймай, опера, симфония, балет, кино өнерінің алғышарты болды.

Оратория жазу барысында, Ғ. Жұбанова әр дайындықтан кейін ноталарды үйге алып кетіп, кейбір эпизодтардың жаңа нұсқаларын жазып жүретіндей болған. Яғни, орындаушы мен композитор арасында тығыз шығармашылық бірлестік қалыптасты. Ал, бұндай бірлестік жоғары деңгейлі нәтижеге қол жеткізуге мүмкіндік берді. Капелла үшін музыка жазып, капелламен жұмыс жасау композитор шығармаларының шынымен резонанс тудыратындай деңгейге жетуіне әсер етпей қоймады.

1917 жылдан бастау алған Кеңес Одағындағы Лениниана аталатын өнер туындалары жиынтығы Ғ. Жұбанова шығармашылығында үлкен орын алды. 70 -жылдары Ғ. Жұбанова Ленин тақырыбына арналған трилогиясын жазуды қолға алды. Аталмыш кезеңде Орыс композиторларымен қатар, барлық Кеңес республикаларының композиторлары Ленин тақырыбын ұстанды. Музыкадан тыс, театр, әдебиет және бейнелеу өнерінде Ленин тақырыбы өзекті болды. А. Крейн, А. Хачатурян, Д. Гаджиев, В. Шебалин және Д. Шостакович сынды композиторлар осы тақырыпқа симфония жазса,
В. Маяковский мен А. Ахматова өлеңдер жинағын арнаудан тайынбады. Ал, Ғ. Жұбанова Ленин тақырыбындағы ораторияларында философиялық және тарихи-революциялық жоспарды жалпылайтын, өте бейнелі, рельефті және ассоциативті музыка жазу тенденциясын қалыптастырды (Тараканов 208).

Ғ. Жұбанова торилогиясының екі бөлімі оратория жанрында жазылған. Бірінші оратория «Ленин» 1970 жылы жазылған. Бұл оратория композициялық тұрғыда өңдеулер негізінде құрылған бағдарламалық оратория түрін анықтайды. Драматургиялық сюжетке бағынбайтын жаңа, ораторияның еркін формасы, кейінгі буын композиторларының шығармашылығында кеңінен қолданыс табады.

«Арал аңызы» ораториясы 1987 жылы «Ленин» трилогияның екінші бөлімі ретінде жазылған. Бұл ораторияның жазылуын композитор, Алматы қаласында орган аспабының алғаш пайда болуымен байланыстырады. «Арал аңызы» ораториясының қазақ композиторлық мектебіне енгізген жаңалығы, тікелей осы классикалық орган аспабы мен ұлттық домбыра аспабының үндестігінде. Бұл мысал, қазақ композиторларының арасында классикалық жанрларға енгізген жаңа композиторлық шешімдер саласын кеңейтеді, қазақ ұлттық аспаптар оркестрінің орындалуына арналған ораториялардың пайда болуына әкеледі. Абай атындағы опера және балет театрының директоры көркемдік жетекшісі Ғазиз Дугашевтың дирижерлауымен өткен премьерасы алғашқы және соңғы орындалуы болып қалғанымен, бұл шығарма қазақ классика өнерінің құнды мұрасы саналады.

Еуропалық орган мен дәстүрлі домбыра аспабының контрасты заманауи үндестік тудырып қана қоймай, драматургиялық тұрғыда ұлттық эпос сипатын толықтырушы 
қызмет атқарды. Қазақ ораториясында алғаш пайда болған, заманауи лироэпостық шығарманың драматургиялық театрлануы, концерттік практикада тың жаңалық болды (Долинская 206).

Ғазиза Жұбанованың прогрессивті шығармашылық ұстанымы және ұлттық дәстүрлерге қатысты белсенділігі «Арал аңызы» ораториясының алғашқы қойылымынан жетістікке деген ықпалын анықтайды. Қазақ халқының музыкалық мәдениетінің сарқылмас байлығын қамтитын ұлттық фольклор, композитор шығармашылығының шабыт көзін құрады. Сонымен қатар, дәстүрлі речитативті-әңгімелеу стилі, тән жанрлар, семантикалық тұрғыдан маңызды ладтық-интонациялық және ритмдік формулалардың музыкалық құрылымына үйлесімді түрде енгізілуі, формасы - Ғазиза Ахметқызы шығармаларындағы эпостың көркемдік құралдарын қолданудағы маңыздылығын куәландырады (Аязбекова 82).

Ғазиза Жұбанованың «Арал аңызы» ораториясының алғашқы орындалуында мәнерлеп оқушы Ф. Шарипова, домбырашы Қ. Ахмедияров, солисттер Б. Тулегенова, К. Магавин, Е. Серкебаев болды. Хор капелласының жетекшісі А. Молодов, А. Жұбанов музыка мектебінің балалар хоры жетекшісі В. Мамизеров және Мемлекеттік симфониялық оркестр дирижеры Т. Абдрашев қызмет атқарған.

«Салтанатты оратория» шығармасы да Ғ. Жұбанованың бір рет қана орындалған ораторияларының бірі. Қолжазба күйінде сақталған ораторияның жалғыз нұсқадағы оркестрлік партитурасы 2020 жылы Құрманғазы атындағы қазақ ұлттық консерваториясының кітапханасына тапсырылған Қазақ композиторлар одағының базасында тіркелген.

Ал, жекелеген хор партитурасын

Б. Байқадамов атындағы мемлекеттік капелланың нота архивынан кездестіруге болады.
Мемлекеттік тапсырыс бойынша Ресей мен Қазақстан достастығының 250-жылдық мерейтойына арналған шығарма заманауи қайта жаңғыртуды талап етеді. Себебі, Тәуелсіз Қазақстан мәдениетінде ұлттар достастығы тақырыбы әлі күнге дейін өзектілігін жоғалтпаған. Музыкалық негізін құрайтын «Дударай» әні қазіргі эстрадада аса танымалдылыққа ие шығарма.

Л. И. Брежневтың «Целина» кітабы желісінде жазылған «Нан мен ән» ораториясы алғышқы рет Алматы қаласының Республика сарайында А.В. Молодовтың жетекшілігімен орындалған болатын. Кейін, Мәскеу, Ташкент және Тбилиси қалаларында орындалып, жоғары ілтипатқа ие болған. Бірақ өкінішке орай, уақыт өте келе «Нан мен ән» ораториясы өзектілігін жоғалтып, баспадан басылып шықпады. Құрманғазы атындағы ұлттық консерватория кітапханасында сақталған, ораторияның оркестрлік партитурасы, осы күнге жеткен жалғыз данасы болып табылады.

Құрылым ерекшелігі бойынша «Салтанатты оратория» және «Нан мен ән» ораториялары кантата жанрына жақын, шағын көлемді «Кеңестік оратория» топтамасына жатады. А. Хохловкинаның берген анықтамасы бойынша бұл ораториялар тобы, классикалық ораториядан драматургиялық баяндау формасымен және өте шағын көлемімен ерекшеленеді. Бұл екі «мерейтойлық» ораториялар қазақ музыка мәдениетінде ерекше орынды иеленген шығармалар топтамасының алғышарты болып табылады. М. Сағатов, М. Манғытаев және Б. Баяхуновтың шығармашылығында жалғасын тапқан салтанатты дәріптеу дәстүрінің негізгі бастауы саналады.

Ғ. Жұбанованың Абай ақынның 150 -жыл мерейтойы қарсаңында жазған «Татьяна әні» ораториясы 1983 жылы жазылып, 1984 жылдың 
12 сәуірінде алғашқы орындалуы болды. Кейінгі жылдары бұл оратория бірнеше авторлық концертте және композитордың мерейтойына арналған концерттерде орындалып жүрді. «Татьяна әні» ораториясының жеке вокалдық партиялары «Вокалдық өнер» кафедрасында ерекше танымалдылыққа ие және қанша уақыт өтсе де орындаушылық репертуардан түспеген(Алибекова 194).

1987 жылы Ғ. Жұбанова «Возлюби человек человека» ораториясын жазып, 1988 жылдың наурыз айында алғышқы орындалуы өтті. Баспадан шыққын партитурасы болмағандақтан бізге дейін ораторияның аудио нұсқасы ғана сақталған. Зерттеудің негізгі материалы реттінде пайдаланылатын сол премьера таспасы. Кейін 2012 жылы «Моление о мире» атымен CD таспада жарияланған. Таспадаға орындаушылардың құрамы: Chorus - Государственная Хоровая Капелла Казахской ССР, Детский хор специальной средней музыкальной школы имени Ахмета Жубанова, Conductor - Анатолий Молодов, Тулепберген Абдрашев, Kyl-kobyz Рахия Абильтаева, Orchestra Государственный Симфонический Оркестр Казахской CCP, Read By Юрий Капустин, Saz-syrnay - Гульнара Бекетаева, Shan-kobyz - Гульсара Пиржанова, Soloist - Ермек Серкебаев, Қайрат Магавин, Людмила Асланова, Хорлан Калиламбекова (Жубанова 187).

Осы тұрғыда, 1990 жылы «Музыкальная жизнь» журналының № 5 номерінде жарияланған С. Шубинаның «Возлюби человек человека» ораториясының орындалуына жазылған рецензиясына тоқталып өтейік. «Қазақстан композиторлық мектебінің танымал жетекшілерінің бірі Ғазиза Жұбанованың жаңа ораториясы, премьерада болған адамдар арасында түрлі пікірлер тудырды; олардың кейбіреулері бір-бірінен қатты айырмашылық тудырды» дейді.
Ғ. Жұбанованың ораториясы сияқты үлкен, күрделі, философиялық тұрғыдан бай композицияны әр түрлі бағалау табиғи нәрсе. Алайда, шығарманың танымал композитордың қаламынан шыққанын мойындау кезінде «пікірлердің плюрализмі» болуы табиғи құбылыс, бұл олардың авторын органикалық түрде тағы бір рет таң қалдырды, өзінөзі қайталамауды қабылдамады және «олардың жетістіктеріне сүйенеді» деген ойды қалыптастырады.

\section{Талқылау}

Ғ. Жұбанова ораторияларының орындалу тарихында композитордың авторлық кештерінің маңыздылығы зор. Алғашқы авторлық концерт 1966 жылы 20 мымырда Алматыда өтті. Онда композитордың камералық туындыларымен қатар a'capella хор шығармалары және алғашқы «Арайлап атқан таң» ораториясының үзінділері орыналды. Екінші авторлық концерт 1975 жылы желтоқсан айында Алматы қаласында өтті. Ал, кейінгі авторлық кештер Ленинград және Мәскеу қалаларында өтті. 1986 жылы П. И. Чайковский атындағы Мәскеу консерваториясының үлкен залында өткен авторлық концертте Ғ. Жұбанованың «Арал аңызы» ораториясы орындалып, аудио таспаға жазылған болатын (Мамбетов 5).

Композитордың кезекті авторлық концерті 1991 жылы 21 желтоқсанда Алматы қаласында өтті. Осы авторлық концертте Ғ. Жұбанованың «Татьяна әні», «Арал аңызы» ораторияларымен қатар Екінші симфониясы орындалды. Ал, кейінгі 1992 жылы 19 сәуір күні Алматыда өткен Ғ. Жұбанованың камералық музыкасының авторлық концерті композитордың көзі тірісінде өткен соңғы авторлық концерті болды.

Советтік мемлекеттердің музыкалық мәдениетінде ерекше жауапкершілік композиторлар одағына жүктелді. 
1957 жылы КСРО Композиторлар одағының II съезінде алғашқы құрамға кіргеннен бастап, Ғ. Жұбанова барлық съездер мен жиындарға қатысып, шығармаларын басқа мемлекет композиторларына паш етуден тартынбаған. 1962 жылы Композиторлар одағының III съезінде төраға сайланып, «Арайлап атқан таң» ораториясының орындауы ерекше ықыласқа ие болды. Кейін КСРО Композиторлар одағының IV (1968), V (1974), VI (1979), VII (1984), VIII ( 1991 ) съездерінде композитордың шығармалары дәстүрлі түрде концерттік бағдарламасына еніп жүрді (Кетегенова 320).

Мемлекетіміз 1991 жылы тәуелсіздік алғаннан кейін қоғамдық өмір мен саяси құрылым күрт өзгеріске ұшырады. Осыған байланысты мемелекетіміздің мәдени өмірі үйреншікті даму бағытынан тайды. Соңғы рет 2017 жылы Ғ. Жұбанованың 90-жылдық мерейтойына Қазақстанның түкпіртүкпірінде концерттер өткізілді. Астана қаласының «Астана» концерт залында (5 қараша) және «Астана Опера» театрының сахнасында (30 қараша) Симфониялық оркестр, Қамералық хор және жеке солисттердің қатысуымен концерттер өтті. Гүлмира Құттыбадамованың жетекшілігіндегі камералық хор Ғ. Жұбанованың «Татьяна әні» ораториясының хор бөлімдерімен қоса, А. Сарсенбаевтың сөзіне жазылған a'capella хор циклын орындады.

Сонымен қатар, композитордың туған жері Ақтөбе қаласының Ғ. Жұбанова атындағы облыстық филармонияның Мербол Құспановтың жетекшілігіндегі Қазақ камералық хоры 14 маусымда үлкен хор концертін өткізді. Аталған концертте Ғ. Жұбанованың хорға арналған өңдеулерімен қатар, оратория шығармаларының үзінділері орындалды. 2018 жылдың 13 сәуірінде Алматы қаласындағы Жамбыл атындағы қазақ мемлекеттік филармониясының Мемлекеттік хор капелласы «Из травы я взлетела» атты мерекелік ән кешін өткізді (Кузембай 490).

Соңғы онжылдықта Ғ. Ахметқызының хор шығармалары мерейтойлық концерттермен қатар, мамлекетіміздің жоғарғы музыкалық білім беру ордаларында жиі орындалады. Жыл сайын жоғары білікті хор дирижерлерін даярлап шығаратын Құрманғазы атындағы қазақ ұлттық консерваториясы мен Қазақ ұлттық өнер университеті Ғ. Жұбанованың хор шығармаларын мемлекеттік емтихандардың міндетті бағдарламасына енгізген. Осы тұрғыда ҚазҰӨУ студенттік хоры мен консерватория хоры композитордың оратория шығармашылығын толық игерген дей аламыз.

Г. Л. Арикайненің айтуы бойынша: «Қазақстан композиторларының қаламынан шыққан ораториялардың алғашқы және негізгі орындаушылары болып табылатын Мемлекеттік хор капелласы, сол заман композиторларының басты практикалық кеңістігін құрады». Көп жағдайда шығарма премьерасының сәтті немесе сәтсіз өтуі осы ұжымның кәсіби орындау деңгейіне тәуелді болды. Композитор мен орындаушылардың арасында пайда болған шығармашылық одақ, екі жақты жауапкершілікті талап етіп, жалпы қазақ музыка мәдениетінің даму негізін құрады. Орындаушылар алдына қойылған техникалық және көркемдік міндеттер абыроймен атқарылып қана қоймай, сатылы түрде жүріп жатқан орындаушылық даму процессінің қарқынды жүруіне үлес қосты. Басқалай айтқанда, оратория жанры қазақ хор мәдениетінің жаңа белестерді бағындыруына себеп болды (Арикайнен 47).

Қазақ хор мәдениетінің қалыптасуына ерен еңбегін аямай, алғашқы әйел-дирижер атанған Гүлжазира Ахметқызының «Восхождение. Маэстро и Казахская капелла» атты еңбегінде Қазақ композиторларының 
ораториялық шығармашылығына қатысты көп деген мағлұматтар жиналған (Ахметова 61 ). Ораториялардың капелла репертуарындағы алатын орны жайлы, мемлекетімізде алғашқы рет көп дауысты a'capella шығармаларын орындаушы ұжым атанған капелланың жаңа классикалық жанрды меңгеруге деген ынтасы жайлы айтылған. Орындаушылық тарихын хорға арнап өңделген халық әндерінен бастаған ұжым, уақыт өте келе кәсіби біліктілігін жаңа деңгейге жеткізді. Мемлекеттік капелла еліміздің барлық мәдени іс-шаралары, концерттер мен композиторлардың шығармашылық кештерінің қадірлі қонағы болды. Капелланың репертуарына енген жас композиторлардың ораториялары ұлттық музыка мәдениетіміздің «жарқын көрсеткіші» атанып, одақтастық ауқымында сұранысқа ие болды. Қазақ композиторлараның ораториялық шығармалары мемлекетіміздің кәсіби хорлары мен кәсіби оркестр ұжымдарын бір сахнаға біріктіріп қана қоймай, Белорусия, Украина, Молдовия, Грузия, Армения, Эстония және Латвия мемлекеттерінде өткен жиындарда орындалатын мемлекеттік мұраға айналды (Недлина 162).

\section{Қорытынды}

Қазақ музыка мәдениетінде ораториялық музыканың алатын орны ерекше. Себебі, ол қазақ композиторларының классикалық жанрларды игерудегі сәтті даму жолын жүріп өткен жанр. Ұлттық фольклор үлгілеріне жаңа леп беру арқылы, жаңа әлемдік кеңістікке шығару жолдарының бірі саналады. Музыканың әлемдік даму қарқынынан еш қалыспайтын ұлттық мұрамыз тынымсыз дамуда. Оның ішінде, жекелеген вокалық-хор мәдениетінің уақытша құлдырау көрсеткіші соңғы жылдары «Shine Astana» және «Astana - voice of the world» сынды хор ұжымдарына арналған әлемдік жобалар арқылы жаңа қарқынға ие болуда деген сенімдеміз (Sheinbaum 108, Howard 412).

Осылайша, Ғ. Жұбанова ораторияларының кеңестік кезеңдегі және тәуелсіз Қазақстан сахнасындағы орындаушылық практикасын саралай отырып, оратория жанрының белгілі кезеңде белсенді дамуы мен уақытша құлдырау себептері ашыла бастады. Әрине бірінші себеп, кез келген ораторияның тақырыптық өзектігі болып табылады. Белгілі кезеңде қоғамдық талап негізінде жазылған ораториялар сол уақытта аса белсенді ротацияға ұшырап, танымалдылықтың ең жоғарғы кезеңін өткізеді. Екіншіден, ораторияның көлемді орындаушылық ерекшелігінде. Толық құрамды симфониялық оркестр мен аралас хор орындауына арнап жазылған ораториялар, белгілі кезеңде үлкен орындаушылық қиындыққа ұшырады. Орындаушылар құрамының толық болмауы және орындаушылық техниканың күрт әлсіреуі ораториялық музыканы концерттік эстрададан біржола сырып тастады. Оған дәлел, кейінгі кезеңде жазылып, орындалуы іске аспай, тек қана қағаз беттерінде сақталған ораториялар саны болып табылады. Үшіншіден, қазақ композиторлық мектебінде қалыптасқан жаңа шығармашылық лептің камералық жанрлар бағытында дамуы. Бірақ, ол алдыңғы себептер негізінде қалыптасқан құбылыс болуы мүмкін. 


\section{Дәйеккөздер тізімі}

Sheinbaum, John J. Good music: what it is and who gets to decide. Chicago, The University of Chicago Press, 2019.

Smither, Howard E. A history of the oratorio: vol. 4: the oratorio in the nineteenth and twentieth Centuries. The University of North Carolina Press, 2012.

Алибекова, Бибигуль. "Казахское хоровое искусство сегодня". Музыкальная академия, № 4, 2011, с. 193-195.

Арикайнен, Георгий. Хоровое пение в Казахстане. Алма-Ата, Казахстан, 1965.

Ахметова, Гульжазира. Восхождение маэстро и казахская капелла. Алматы, 1999.

Аязбекова, Сабина. Мир музыки Г. Жубановой: время - культура - этнос. Алматы, Институт философии и политологии МОН РК, 1999.

Джумакова, Умитжан и Гульнар Абдрахман. Приношение Газизе Жубановой: научно-документальный портрет. Астана, Фолиант, 2017.

Жубанова, Газиза. "О кантатах и ораториях". Газиза Жубанова. Мир мой музыка (статьи, очерки, воспоминания). Алматы, Білім, 2008, с. 185-192.

История современной отечественной музыки: учебное пособие. Вып. 2. Редактор-составитель М. Е. Тараканов, Москва, Музыка, 1999.

История современной отечественной музыки: учебное пособие. Вып. 3. Редактор-составитель Е. Б. Долинская, Москва, Музыка, 2001.

"Казахская кантатно-ораториальная музыка в контексте идеи независимости". Дәстүрлі музыка мен композиторлық шығармашылықтағы тәуелсіздік идеясы, жауапты редактор Сара Күзембай. Алматы, Print Express, 2011, с. 475-537.

Кетегенова, Нургиян. Творческие портреты композиторов Казахстана. Алматы, Алатау, 2009.

Мамбетов, Алиби. «Роль Газизы Жубановой в мировом искусстве XX века». Газиза Жубанова и музыка XX века: материалы международной научнопрактической конференции, Алматы, КНК им. Курмангазы, 2008, с. 3-6. Недлина, Валерия. Пути развития музыкальной культуры Казахстана на рубеже XX-XXI столетий. 2017. ФГБОУ ВО «Московская государственная консерватория имени П. И. Чайковского", кандидатская диссертация.

Сапарова, Назым. Азербайжан Мамбетов: Путь к славе. Алматы, Полиграфкомбинат, 2021.

Томашевский, Мечислав. Шопен: человек, творчество, резонанс. Перевод с польского Левона Акопяна и Елены Янус, Москва, Музыка, 2011. 


\section{References}

Alibekova, Bibigul'. “Kazahskoe horovoe iskusstvo segodnya.” [“Kazakh choral art today."]. Muzykal'naya akademiya, №4, 2011, pp. 193-195. (In Russian)

Arikajnen, Georgij. Horovoe penie v Kazahstane [Choral singing in Kazakhstan]. Alma-Ata, Kazakhstan, 1965. (In Russian)

Ahmetova, Gul'zhazira. Voskhozhdenie maestro i kazahskaya kapella [The ascent of the maestro and the Kazakh chapel]. Almaty, 1999. (In Russian)

Ayazbekova, Sabina. Mir muzyki G. Zhubanovoj. Vremya - kul'tura - etnos [The world of music by G. Zhubanova. Time-culture-ethnos]. Almaty, Institut filosofii i politologii MON RK, 1999. (In Russian)

Dzhumakova, Umitzhan and Gul'nar Abdrahman. Prinoshenie Gazize Zhubanovoj: nauchno-dokumental'nyj portret [Tribute to Gaziza Zhubanova: scientific and documentary portrait]. Astana, Foliant, 2017. (In Russian)

Zhubanova, Gaziza. “O kantatah i oratoriyah.” [“On cantatas and oratorios.”]. Mir moi - Muzyka (stat'i, ocherki, vospominaniya) [My World - Music (articles, essays, memoirs)] by Gaziza Zhubanova. Almaty, Bilim, 2008, pp. 185-192. (In Russian)

Tarakanov, Mikhail (editor). Istoriya sovremennoj otechestvennoj muzyki [History of contemporary Russian music]. Moscow, Muzyka, 1999. (In Russian)

Dolinskaya, Elena (editor). Istoriya sovremennoj otechestvennoj muzyki [History of contemporary Russian music]. Moscow, Muzyka, 2001. (In Russian)

"Kazakh cantata-oratorio music in the context of the idea of independence." Dastyrli muzyka men kompozitorlyk shygarmashylyktagy tauelsizdik ideyasy [The idea of independence in traditional music and composing], edited by Sara Kazembay. Almaty, Print Express, 2011, p. 475-537. (In Russian)

Ketegenova, Nurgiyan. Tvorcheskie portrety kompozitorov Kazahstana [Creative portraits of composers of Kazakhstan]. Almaty, Alatau, 2009. (In Russian)

Mambetov, Alibi. “Rol' Gazizy Zhubanovoj v mirovom iskusstve XX veka.” ["The role of Gaziza Zhubanova in the world art of the 20th century."]. Materials of the International scientific-practical conference Gaziza Zhubanov and music of the twentieth century. Almaty, KNK im. Kurmangazy, 2008, p. 3-6. (In Russian)

Nedlina, Valeriya. Puti razvitiya muzykal'noj kul'tury Kazahstana na rubezhe XX-XXI stoletij [Ways of development of the musical culture of Kazakhstan at the turn of the 20-21th centuries]. 2017. Moscow, Moscow State Concervatory, PhD Thesis, www.mosconsv.ru/upload/images/Documents/DiserCand/nedlina_dissertation.pdf. Accessed 10 August 2021. (In Russian)

Saparova, Nazym. Azerbajdzhan Mambetov: Put' k slave [Azerbaijan Mambetov: Path to glory]. Almaty, Poligrafkombinat, 2021. (In Russian) 
Sheinbaum, John J. Good music: what it is and who gets to decide. Chicago, The University of Chicago Press, 2019.

Smither, Howard E. A history of the oratorio: vol. 4: the oratorio in the nineteenth and twentieth centuries. The University of North Carolina Press, 2012.

Tomashevskij, Mechislav. Shopen: chelovek, tvorchestvo, rezonans [Chopin: man, creativity, resonance]. Moscow, Muzyka, 2011. (In Russian)

\section{Дилара Карекенова}

Қазахский национальный университет искусств (Нур-Султан, Казахстан)

\section{ВЛИЯНИЕ ОРАТОРИЙ ГАЗИЗЫ ЖУБАНОВОЙ НА СОВРЕМЕННУЮ КАЗАХСКУЮ ХОРОВУЮ КУЛЬТУРУ}

Аннотация. Статья направлена на изучение исполнительской практики ораторий Газизы Жубановой. Оратории 60-90-х годов XX века не только стали ценным образцом казахской хоровой культуры, но и подняли ее развитие на новый уровень. В последние годы широко изучается хоровое творчество Г. Жубановой. Однако вопрос об истории и практическом значении самого ораториального искусства игнорируется. История исполнения ораторий композитора в советский период и на сцене независимого Казахстана раскрывает актуальность вокально-симфонического жанра разных периодов. Поэтому основная цель данной статьи - определить влияние жанра оратории на формирование и развитие национальной хоровой культуры на основе истории исполнения.

Для установления жанрового характера оратории в казахской хоровой культуре в ее полный исторический период (1960-2020 гг.) национальный исторический опыт соотносится с глобальными процессами ораториального искусства. Исходная методологическая позиция заключается в признании этого явления неделимым целым. Статья содержит научные знания о жанре оратории, творческих особенностях музыкального искусства, жизни ораториальных произведений русских и западноевропейских классиков в премьерах и публикациях. В качестве материала - музыкальные тексты ораторий Г. Жубановой, сохранившиеся в печати, рукописи, клавиры, аудио- и видеозаписи. При изучении сценической практики ораторий Г. Жубановой были выявлены особенности группы “юбилейных ораторий» среди ораторий историко-патриотических, т. е. исполнительская практика данных произведений напрямую зависела от тематики. При обсуждении результатов исследования оратории Г. Жубановой были разделены на “историко-патриотическую”, «юбилейную" и “философскую» группы. Сделан вывод, что в основе данного деления не только тема, но и история написания, особенности развития сюжета оратории. Результаты статьи показывают практическое значение музыковедения для исследований в области вокальной музыки. На основе изучения ораторского искусства Г. Жубановой возможно углубленное изучение темы казахской хоровой музыки в целом, а также ораторского искусства казахских композиторов.

Ключевые слова: оратории Газизы Жубановой, казахская хоровая культура, исполнительская практика, тема оратории, жанровые особенности оратории.

Для цитирования: Карекенова, Дилара. “Влияние ораторий Газизы Жубановой на современную казахскую хоровую культуру». Central Asian Journal of Art Studies, т. 6, № 3, 2021, c. 108-120. DOI: 10.47940/cajas.v6i3.461. 
Dilara Karekenova

Kazakh National University of Arts

(Nur-Sultan, Kazakhstan)

\section{THE INFLUENCE OF GAZIZA ZHUBANOVA'S ORATORIES ON MODERN KAZAKH CHORAL CULTURE}

Abstract. The article is aimed at studying the performance practice of Gaziza Zhubanova's oratorios. Oratorios of the 60-90s of the twentieth century are not only a valuable example of Kazakh choral culture but have also raised the development of Kazakh choral culture to a new level. In recent years, Zhubanova's general choral work has been widely studied. However, the question of the history and practical significance of the oratorical art itself is ignored. The history of the performance of the composer's oratorios in the Soviet period and on the stage of independent Kazakhstan reveals the relevance of this vocal-symphonic genre to different periods. Therefore, the main goal of this article is to determine the influence of the oratorio genre on the formation and development of national choral culture based on the history of performance.

To establish the genre features of the oratorio in Kazakh choral culture in its full historical period (1960-2020), the national historical experience is correlated with the global processes of oratorio art. The initial methodological position is to recognize this phenomenon as an indivisible whole. The article contains scientific knowledge about the genre of oratorio, the creative features of this musical art, and examines the life of oratorio works from Russian and Western European classics in premieres and publications. This work draws on musical texts of Zhubanova's oratorios, claviers preserved in print and manuscripts, and audio and video recordings as material evidence. When studying the stage practices of Zhubanova's oratorios, the peculiarities of "jubilee oratorios" among oratorios on historical and patriotic themes is identified. That is, the performing practice of oratorios is directly dependent on this topic. When discussing the results of the study, Zhubanova's oratorios are divided into "historical-patriotic", "anniversary" and "philosophical" groups. It depends not only on the thematic basis, but also on the history of writing and the peculiarities of the development of the plot. The results of the article show the practical importance of musicology for research in the field of "vocal music." Based on the study of Zhubanova's oratories, an in-depth study of the theme of Kazakh choral music in general or the oratory of Kazakh composers is possible.

Keywords: oratorios by G. Zhubanova, Kazakh choral culture, performing practice, oratorio theme, genre features of oratorio.

Cite: Karekenova, Dilara. "The influence of Gaziza Zhubanova's oratories on modern Kazakh choral culture." Central Asian Journal of Art Studies, vol. 6, no. 3, 2021, pp. 108-120. DOI: $10.47940 /$ cajas.v6i3.461.

\section{Автор туралы мәлімет:}

\section{Дилара Талғатқызы}

Қарекенова - өнертану магистрі, докторант, Қазақ ұлттық өнер университетінің хор дирижерлау кафедрасының оқытушысы (Нұр-Сұлтан, Қазақстан)

\section{Сведения об авторе:}

\section{Дилара Талгатовна}

Карекенова - магистр искусств, докторант, преподаватель кафедры хорового дирижирования Казахского национального университета искусств (Нур-Султан, Қазахстан)

\section{Author's bio:}

Dilara T. Karekenova Master of Arts, Doctoral

Student, Lecturer, Department of Choral Conducting, Kazakh

National University of Arts

(Nur-Sultan, Kazakhstan) 